O

\title{
Speculations on the Mediterranean Borderscape: Le Baiser de Lampedusa
}

Silvia Ruzzi

\begin{abstract}
Authors of academic research on globalization often employ watery metaphors fluidity, circulation, flows - in attempt to analyze the unlimitedness of movements of capital, commodities, ideas, and people. The frictionless sea has thus come to be the metaphor of circulation par excellence. Yet, in the last two decades, the hardening of migration policies all over Europe and beyond EU borders, which has aimed at strengthening a water-barrier between Europe and its "southern beyond", compels for a consideration of the maritime space, the Mediterranean Sea, as b/order space(s). Through a geo-literary analysis of the novel Le Baiser de Lampedusa (2011) by Mounir Charfi, I will focus my attention on the ways in which the Mediterranean Sea is rendered, modeled and reflected as a b/order space in and through literary representation. The author through the close association of the ordinary and the fantastic, and employing a narrative mode that undermines realism, creates an alternative description of the Mediterranean borderscape in which basic assumptions of referentiality do not hold anymore. In fact, throughout the narrative, the notion of the Mediterranean sea is challenged and its visual appearance becomes blurred and disappears. As a consequence of its disappearance, continents shift and geographic regions are subverted. What emerges is first that the understanding of the Mediterrannean Sea as a b/order is put into question, and secondly, that geopolitical delimitations are not only arbitrary but also flexible. Therefore, the following article deals with the realm of counterfactual geography in border fiction.
\end{abstract}

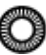

\section{Introduction}

Counterfactual exercise into the literary realm relies on the fictional treatment of the "what if" scenario that deliberately deviates from accepted versions of "reality." It consists of a speculative literary experiment which explores possible realms or meditates on the impossible and unrealizable. ${ }^{2}$ Understood as an experiment, it has the potential for imagining and creating alternatives to the present state of things and it constitutes an immersion into the ontologically unreal. ${ }^{3}$ Counterfactual novels do not actually deny real events and places. Instead, through specific narrative devices, they introduce new interpretations by making up alternative facts and spaces. Like other novels, counterfactual novels 
include numerous references to places, names, and social or political circumstances, but whereas "traditional" novels tend to situate their plot in actual settings, counterfactual novels interfere with at least one of the cornerstones of actual geography, or geo-space, by altering it. They create counterfactual versions of space; their plots suggest altered or even newly outlined geopolitical borders and are set in changed geographical framework in order to put the established representation into perspective, and to draw attention to chance and contingency (Widmann 188). Therefore, counterfactual fiction produces different scenarios, imaginary places, or spatial assemblages, counterfactual geographies, which are, nevertheless, not totally imaginary worlds, but altered ones.

The primary focus of my analysis is Mounir Charfi's novel Le Baiser de Lampedusa (2011). Through the close association of the ordinary and the fantastic, and by employing a narrative mode that undermines realism, Charfi creates a counterfactual representation of the Mediterranean borderscape. ${ }^{4}$ Throughout the narrative, the notion of the Mediterranean Sea is challenged while its visual appearance becomes blurred and disappears. As a consequence of its disappearance, continents shift and geographic regions are unsettled. What is supposed to be south is not south anymore, and sections of the north become south and vice versa. This inexplicable occurrence appears to coincide with the coming together of two alchemist volumes, while the disappearance of the Mediterranean Sea sets in motion a chain of counterfactual events that, in turn, promotes the production of a counter-discourse of the Mediterranean borderscape. Le Baiser de Lampedusa echoes the thoughts of Sandro Mezzadra and Brett Neilson, who argue that the contemporary debate around the concept of border is infused with "a sense of cartographic anxiety" (7) by stressing the troubled connection between borders and the instability of their contours. 5 Charfi's counterfactual geography questions the possibility of a single, unbiased 
perception of space, interrogates conventional spatial understandings, and revisits the cartographic representation of the world in order to emphasize the power of maps in the construction of spatial perceptions according to the "official" ideology of the present. ${ }^{6}$

In addition to the narrational use of the counterfactual in Charfi's novel, this essay explores the ways in which the Mediterranean Sea is rendered, modeled, and reflected as a b/order space in narrative as well as the correspondence between the border as rendered in the literary texts (the presented space) and the border of the textual representation itself (the space of representation). The degree of correspondence between the literary space and the referential world can differ from one to infinity, and, when the reference between fiction and reality becomes precarious or even impossible, such interplay engenders defamiliarization and reader disorientation. Yet even though the presented space and the space of representation seem to be incompatible, these two spaces are coextensive. Before analyzing the novel, I will first outline some of the connective avenues between geocriticism and border studies that foreground my analysis.

The principal interest in geocriticism is the interdisciplinary investigation of space: its particularity resides in being a geocentric method of analysis, concentrated on comprehending a particular space (through the problematics of representation), rather than focusing on a given set of representations (through the thematic of space). A geocritical analysis would approach a literary production by first focusing on its specific space (geographical location) instead of on the author or the historical and cultural context. In Geocriticism: Real and Fictional Space, Bertrand Westphal claims that "[g]eocriticism probes the human spaces that the mimetic arts arrange through, and in, texts, the image, and cultural interactions related to them," thus stressing close affinities between the fictional spatiality and the outer one (6). Moreover, he suggests that the theory of 
geocriticism locates the concept of space at the center of spatial literary analyses and therefore avoids the "egocentered logic," which interprets the ways in which literature informs a particular space through the author's or characters' perspective (111). In other words, geocriticism is the investigation of the relationship between geo-spaces and fictional or imagined ones. It relies on the "interface of the world and the text"7 and reveals "hidden relations of power in space that a critical theory less attuned to spatiality might well overlook" (Westphal 112; Tally 114). Consequently, I suggest that elaborating upon analysis of the Mediterranean Sea through a geocentric approach to literary productions serves as a critical device for border scholars, since it theorizes spatial literary studies as an important way to comprehend and react to b/order issues.

Border studies is a vast and flourishing academic field that explores the widely different, constantly shifting definitions of the border. In the last decades, border studies have developed from a sub-discipline of political science, which mainly directed attention to national borders, into an interdisciplinary field that investigates the notions of borders from a variety of perspectives. In such an interdisciplinary field, many research areas share some notions about the features of studied borders and their functions, and, according to David Newman, one of the shared concepts of the border is that it determines "the nature of group (in some cases defined territorially) belonging, affiliation, and membership, and the way in which the process of inclusion and exclusion are institutionalized" (33). Cultural studies and the humanistic approaches have significant explanatory potential regarding borders and border-crossings in the field of border studies, since "drawing borders is the key to human cognition [and] humans' identity and sense of difference from others is completely dependent on the existence of borders" (Donnan and Haller 8).

The power of literature in articulating the multifaceted layers of the border relies on its capacity for supporting and revising the assumptions and discourses 
around border studies (Prieto 14). Border fiction participates in debates on the b/ordering process, offering other ways to mend traditional limits of intellectual writing, since it supports and revises the assumptions and discourses around border studies, produces some broader awareness about the combined and uneven forms of development at the borderlands, and reconceptualizes the very nature and relevance of the border, as I demonstrate in the following analysis of Le Baiser de Lampedusa.

\section{Geo-literary analysis: Le Baiser de Lampedusa}

Le Baiser de Lampedusa takes place across different historical times: the colonial French rule in Tunisia, Tunisia before the Arab Spring, and a speculative scenario in which the Mediterranean Sea disappears and Europe and Africa are joined together. The novel revolves around the protagonist's experiment, which aims to manipulate the normal course of nature, his impulse to create an alternative scenario of the world, and the consequences that such re-mapping creates for both the characters and space itself. From the beginning the protagonist, a scientist working at the seismological center of Tozeur in Tunisia, reveals his passion for re-mapping existing geo-spaces: "Je me perdais dans la reconfiguration du monde, m'imaginant jongleur de planets" (Charfi 9). ${ }^{8}$ He also wants to find the missing volume of an alchemist book: "Je n'avais plus qu'une obsession: retrouver le premier tome afin de pouvoir lire le second" (17).9

Reuniting the volumes discloses irreversible dangers whose consequences cannot be easily forecast. It precipitates "Un évenement qui naîtrait des entrailles de la terre, bien plus profond que ses couches géologiques, dans ses abysses liquides et brûlantes" (67). ${ }^{10}$ The protagonist witnesses an anomalous deviation from natural laws: Africa starts sliding towards Europe at one kilometer per hour. Once divided, continents begin a centripetal migration as, underneath the 
Mediterranean Sea, the Eurasian tectonic plate clashes against the African one. Nature "enfin décelé un moyen d'assembler plus vite les deux bords de la plaie [...] qu'est la Méditerranée [...] et de suturer les villes côtières" (71)." The sea, once a reliable spatial marker, is being put at risk by the volatility of natural laws. Therefore, nature is able to connect the two continents that have been divided by the maritime borderscape, defined as "un immense bleu fait sur le corps de la terre [...] Un morceau de terre est-il occupé par trente millions d'êtres humains, ceux se croient obligés de ne pas se mêler de l'existence de leurs voisins, fixés comme des racines sur le morceau de terre qui suit" (107).12

In this passage, the sea is described not only as a wound but also as a space that reflects the collision of two referential codes: namely, the juxtaposed matrices of Europe and Africa. The sea is as much a network of reflections, connections, and collisions as it is a geopolitical space. It is a process as well as a place, and it represents a "limit between an inside and an outside, between the cultivated place of the domesticated scene and the strangeness and disturbance of the external world" (Chambers 41). It is also a world-configuring device, since it organizes space by fixing points of reference that consequently locate individuals and objects in relation to it. To be on this or that side of the "immense bruise" means to "either physically perform your belonging within a community or to trespass into another" (Rivera-Servera 1). Such a world-configuring device is also a force of containment that inspires the desire to trespass, motivates bodies to come across, and threatens death by drowning or by capture and murder on the other side.

It is a traumatic bleeding wound that takes away thousands of lives every year. ${ }^{13}$ It is no coincidence that, after comparing the sea to a wound, the protagonist recounts how the situation was prior to the collision of the two continents: 
Les Africains se jetaient par milliers sur les barbelés de I'Europe, leurs corps mutilés par les clous, les coups, les balles [...] Certains étaient pris, rejetés comme des chiens galeux [...] Les survivants revenaient toujours à leurs barbelés. Ils n'avaient qu'un seul mot d'ordre: Passer ou mourir. [...] Ils devaient aussi traverser la mer en payant des passeurs avec les économies d' une vie ou avec des avances sur des contrats d'esclavage. Devenus clandestins, ils noyaient leurs souffrances dans les cales des felouques. L' odeur du mazout étouffait leurs craintes $d$ ' être surpris par les gardes-côtes pendant leur traversée. Et ce court périple tournait souvent au drame: au moindre pépin, ils étaient jetés pas dessus bord par leurs impitoyables hôtes, et finissaient leurs voyages dans la gueule des requins, (113; 4 emphasis in original) $)^{14}$

Thus, the migrants' route from Africa to Europe (prior to the literary re-mapping) was not linear. Their journey was fragmented, and it was complicated in terms of duration, since they were forced to retrace their steps while renewing their points of transit and arrival. Even the maritime journey towards the seemingly reachable other shore became a threatening passage into the unknown, hostility, misery, and death.

Le Baiser presents a different possibility. With the disappearance of the Mediterranean Sea, no border police force controls the flow of people, and men, women, and children initiate their mass displacement and exodus towards the point at which the two continents meet. As a result of the almost complete disappearance of the sea, spaces that had previously been incompatible and noncontiguous are now juxtaposed in order to shape a counter-site in which "real" sites are represented, contested, and reversed. The outcome is a revisionist literary cartography that compresses longitudinal spaces, pressing otherwise disparate places, groups, and events into close proximity. While the continental drift and the clash of geological plates result in frequent earthquakes, the collapse of bridges, and the eruption of Sicilian volcanoes whose boiling lava 
reaches the ever-closer African coast, the island of Lampedusa trembles like a kiss between two lips.

Nowadays, Lampedusa is a node in the mobility across the Mediterranean: it is space that represents the material functioning (or dysfunction) of border control. It is the combination of several border lines that have older and more recent origins: the north-south fault (EU vs. Africa), the south-south one (Mediterranean EU vs. Mediterranean Africa), the south-east one (Mediterranean EU vs. the Middle East). Together with the Mediterranean Sea, it is a neuralgic zone in the geopolitical imaginary of the West. Both Lampedusa and the Mediterranean Sea are spaces in which identities are reified and dichotomized (clandestine/legitimate, vagabond/tourist), while mobility is disciplined, surveilled, and contained. Yet in the novel, the island of Lampedusa intends to become a place of love and reception, not of rejection. The speculative remapping in the novel proposes to reconfigure the outpost of European migration control into a node within a Mediterranean network. Rather than being a space of clashes, the Mediterranean envisioned in the counterfactual mapping is a space of interaction that accommodates non-exclusive categories. The titular "kiss" suggests that Africa and Europe are two complementary entities, historically and geophysically connected. Yet the kiss is ambiguous because it is a kiss between two persons " qui ne se connaissaient pas, ou qui ne se voyaient pas vraiment" (26). ${ }^{15}$ But when it happens,

un baiser pouvaient perturber tout [...] Un moment fort à l'halo trop puissant, que le passé s'efface brusquement et que le futur se met à miroiter en de furieux mirages. A partir de cette faille de l' écorce humaine, le désir de l'autre enfle et fusionne, reféfinissant d'autres limites et d'autres ébauches de chemins. L'autre devient mien, sa pensée est adoptée, son regard désormais adoré est pris comme amer, comme phare. On chemine alors sur ses traces comme si l'on n'avait jamais marché sur aucun autre sentier. $(26-7)^{16}$ 
The kiss between two persons is here an allegory for the encounter between the two continents, standing for interaction, transculturation, métissage, and hybridity. Since the two sides will soon be contiguous and, eventually, merge into one another, the outcome will be ideally a hybrid third space ${ }^{17}$ that neutralizes internal differences and defeats dichotomies. Intimacy, understood as a private relation between individuals, is the way in which the subject contemplates, explores, and obtains knowledge of the self and others (Lowe 21). The kiss, the intimate entanglement, is an interactive relationality between the entities "Europe" and "Africa," one that undermines conventional notions of "inside" and "outside," and highlights that any route the continents might take, or do take, is in relation to their others. Such entanglement underlines the need to take note of and assert that both continents should open themselves onto the other shore. In this sense, current migration is a phenomenon that is part and parcel of both continents, shaped by and shaping Europe and Africa at the same time, and that intimately entangles the two of them. However, as the protagonist claims "[c]e $n$ ' est plus de l'amour, c'est de la folie!" (27). ${ }^{18}$

The continental drift results in an overlapping movement of spatial coordinates and in the close proximity of the two sides. From the African coast, one can see the lighthouses of Sardinian harbors, while, according to Spanish television, Algiers is now in front of the island of Majorca and will soon be few kilometers away from Marseille. As a result of such terrestrial movement, the Mediterranean becomes an inner lake and the strait of Gibraltar closes the ocean off. Contrary to the news that predicted a violent clash between the two continents, the contact between Africa and Europe is gentle, sensual like the caress of a romantic prelude: now Marseille joins Algiers, Bisert connects with Rome, and Sicily is tied together with the gulf of Gabès.

Eventually, as the protagonist suggests, "Le puzzle se reconstituait " (98). 19 
While observing the "puzzle" of the counterfactual geography, one of the characters states that " Les frontières ne sont que le reliquat d'une conception coloniale appelée à disparaître. L'homme doit circuler aussi librement que les marchandises" (79). ${ }^{20}$ Such statements recall the work of Fatma Ben Sliamane, who analyses the shifting and multiple notions of border in the Maghreb region. In her article "Between empire and nation-state: the problem of borders in the Maghreb," she argues that nation-state logic was imported by waves of colonial expansion and that it contrasted with the previous geopolitical logic in the Maghreb. Before colonialism, the notion of borders as limits, and as tools for spatial enclosure and differentiation among populations, was lacking from both the civil and the political imagination (Ben Slimane 53).

David Harvey similarly argues that, in the context of European colonization, spaces "were deterritorialized, stripped of their preceding signification [in order] to be reterritorialized" by colonial administrations (264). Consequently, cartography accompanied and supported colonialism as it surveyed territorial advances, while contemporary geopolitical borders in the Maghreb are not only legacies of the colonial past but also markers of historical ties to the present.

And yet, the call for open borders for commodities and capital has, more than simply reproducing material inequality between the global North and South, also fueled a great unevenness in the South. With the Euro-Mediterranean Economic Area of 1994, the vision of the Mediterranean border as a portal became the favourite metaphor for the economies of both shores. In the global South, deregulation and cross-border negotiation with Europe have tended not only to benefit only a small clique of people but also to increase the polarization of resources. Le Baiser unravels the spatial injustices of dislocation and deterritorialization in the Maghreb that result from policies equating economic progress with globalized commodities and capital. 
While walking through the streets of Marseille - now Maralger - Algerian women look at the shop windows and sadly realize that the dresses, which have been produced by their hard work, are sold in France for the price of one year's salary:

[E]lle était ouvrière dans une usine de textile destinée à l'exportation vers la France, une usine dont les propriétaires bénéficiaient de tous les avantages fiscaux et sociaux, une usine où les ouvrières faisaient les $3 \times 8$ dans des conditions d'esclavage moderne, où toute erreur était sanctionnée par une retenue sur salaire [...] Elle s' était mise à calculer les millions de dinars qu'elle avait fait gagner à son maître pendant les vingt ans de sa misérable existence devant sa machine à coudre. $(96-7)^{21}$

Globalization increases or maintains unequal cross-border exchange: cheap labor on one side facilitates cheaper products for more affluent consumers on the other and, to a certain extent, contemporary trade agreements between historically unequal partners reinvigorate consolidated power structures. Accordingly, the Mediterranean border represents an economic resource, a site for developing business and a profitable alternative to EU enterprises. For them, the border is a barrier that needs to be crossed. In fact, in economic and financial terms, the Mediterranean spatial barrier achieves less and less meaning since it triggers the formations of places in ways attractive to capital. Nevertheless, the outcome has been fragmentation, insecurity, and uneven development within the seemingly unified global space of capital flows, while the Mediterranean border has become the intractable zone of North-South imbalances and "the setting both for sharp socioeconomic contrasts and for several kinds of migratory phenomena, which derive from global inequality and instability" (Ribas-Mateos 22).

The fictional collision of the continents results in a continental contiguity that destabilizes previous ideas of stable territory and sovereignty. Where African 
people walk freely on the other side, the European rhetoric around the disappearance of the border revolves around fear and threat to national security. The Mediterranean used to provide security to Europe, as it functioned as a powerful device to overcome both anxiety towards the unknown and any possible threats coming from the outside. In Le Baiser, however, there is no border that obstructs the flow of people from the South, and Europeans are forced to find alternative ways to "protect" themselves: helicopters fly over the small stretch of the Mediterranean Sea, projecting their lights over the crowd that hurries to the other side, and the inhabitants of Europe are now "Les autochtones d'Europe, ceux qui désormais étaient les nouveaux colonisés, barricadés dans leurs ghettos de luxe" (99). 22 In response to "cette vaste fourmilière humaine en mouvement"23, the army builds a barricade at Gibraltar that looks like " un hymen érigé à la virginité de l'Europe" ${ }^{24}$ meant to prevent "la pénétration des populations africaines non autorisées" 25 (95-6). This description recalls the foundational European myth - that of Europa and the bull - in which Europe was a Phoenician woman who was kidnapped by Zeus, disguised as a white bull. After seducing and raping her, Zeus swims to the island of Crete, located at what is now believed to be the fringes of Europe, where she became a queen. According to this myth, the female and vulnerable Europa is not located at the center of Europe - wherever it might be - but at the outer margins, in the Mediterranean island of Crete. ${ }^{26}$

The "unregulated violation" of the "out-of-place" border by people coming from Africa triggers anxiety and fear among the European population, since the disappearance of the Mediterranean border makes it impossible to differentiate the inside from the outside and, therefore, to separate insiders from outsiders. Such confusion and turmoil contradict the idea of territorial exceptionality, legitimizing the intensified integration of military equipment and personnel into b/ordering activities. In response to the fear of invasion, Europeans 
initiate b/ordering spatial strategies in order "to delimit one's own place in a world bewitched by the [...] powers of the Other" (de Certeau 36). This placeclaiming activity is a protective reaction that functions to reclaim previous territorial and cultural limits. In this regard, the underlying idea is that borders are not only lines on the ground or on a map. They constitute a fundamental feature of the state's political imaginary and its people's political imaginary, functioning as beliefs that create and shape a world, a social reality. Even after the border's material entity disappears and its political and administrative aspects vanish, the memories of the border can still manage and exercise cultural and social power. The maritime border shaped both communities and identities, and, after its fictionalized disappearance, it continues to embrace - albeit as phantoms - specific social spaces.

To recapitulate, in the course of the narrative, the continental drift and the clash of geological plates result in an overlapping movement of spatial coordinates that disturb the previous equilibrium: the Mediterranean has disappeared in order to leave space to a new world. It has lost its previous function of natural boundary. It evaporates, leaving behind a terrifying - for European people - conglomerate of continental contiguity. By presenting a postnational map in which geopolitical borders are challenged and undermined, the counterfactual literary cartography articulates new ways of seeing, perceiving and subverting the border and, consequently, it refers to the appropriation of existing spatial representations and the intrinsic subversion of their previous function. Accordingly, through the Mediterranean border's geopolitical realignment, the literary cartography stresses the fact that not only borders, but also nationstates, are precarious constructs.

Charfi's choice to focus on the shifting of natural resources - the sea and lands - is crucial for the broader context of globality in which the narrative is set. Through the fictionalized disappearance of the Mediterranean as global border, 
the narrative challenges the concept of a rigid geopolitical limit. By suggesting that the geopolitical border, which not only divides two continents but also regulates the division of labour, is a purposeful fiction, the entire novel interrogates the meaning of pre-given denominations and categorizations and the existing power relations between Europe and Africa. Additionally, moving or performing the border off-site reminds us that the border was already an artificial construction. Any cartographic representation evokes a world that elicits a fiction, a fiction based on the illusory existence of a primordial order that needs to be preserved and/or re-established. Following the idea of the fictitious cartographic representation, the border is thus the consequence of a fictional, but very effective arbitration, an act that suggests, in its performativity, not only a dialectical relationship between the sovereign ruling and the fictional representation of order but also the choice of what to include/exclude in the representation.

Nevertheless, the obliteration of the land-sea distinction and the disappearance of the sea have tremendous consequences for the landscape: the sea level rises, flooding coastlines; water putrefies; fish die; and fishermen lose their jobs: "La mer avait fui laissant aux hommes un legs sans profits ni promesses " (146). ${ }^{27}$ The ancient practice of alchemy ${ }^{28}$ and the protagonist's experiment are implicated in a difficult skein of intersecting links among nature, people, and nations. The re-mapping of the geo-space is not without risk, and, towards the end of the novel, the protagonist realizes that his actions have resulted in the estrangement of human beings from, and within, nature. Such alienation intensifies the environmental crises around the disappeared Mediterranean Sea and functions to remind the protagonist that the conditions of living are subordinate to the course of nature.

Furthermore, the counterfactual world-design does not resolve previous cultural/political conflicts between the two shores. Even though the spatial 
notion of maritime border is contested, its presence is undoubtedly tangible, and it regulates the lives of entire communities and populations. Such consideration underlines the fact that, even though space is re-inscribed within a different set of discourses, part of the previous power relations and epistemology persists. In the novel, while the Mediterranean border becomes a permeable and fluid entity, it is simultaneously erected at other sites (within European cities and at Gibraltar). In this sense, the process of reassertion and re-articulation of socially and culturally constructed boundaries implies that a previously challenged existing boundary is re-established in a new guise in response to a contested set of interests. Moved by the desire to strengthen the now porous and disappeared border, Europeans start planning local b/ordering activities and the regulation of mobility in order to preserve a sense of security. Contact zones between the two continents are now the stage for the imposition of new delimitations and, as the protagonist comments, "notre mer Méditerranée devienne une mer morte [...] et pour un lopin de Terre Promise les gens s'entretuent" (155). ${ }^{29}$

Suspecting that his actions may have precipitated the geological aberration that has thrown the population in turmoil, and since power relations intrinsic to the previous world design persist, the protagonist decides to separate the two alchemical volumes and reestablish the previous geo-space. Not only does he realize that the removal of mental boundaries is proving to be more difficult than anticipated, that the call for open borders and free movement can be appropriated to enforce other structures of control, and that "La grande familie universelle des humains est une utopie" ${ }^{30}$, but he also, realizes that "[n]ous n'avons besoin d'aucun manuel d'alchimie pour comprendre la vie. Le sol, les hommes ou le ciel bougeront dans un sens ou dans un autre, et ce n'est pas ma main que les arrêtera" $(107 ; 154) \cdot{ }^{31}$ He becomes aware that he is " ni mage ni devin ${ }^{32}$, that the manipulation of nature demands a complete comprehension 
of the web of historical, cultural, ideological, and political relations in which the Mediterranean borderscape is embedded (87).

Thus, as a consequence of the two volumes' detachment, the two continents drift apart again, the water flows back into the Mediterranean basin, the earth stops trembling, and nature returns to its previous course.

This second re-mapping reveals, once again, that space is not a static, passive, and unchanging entity. Rather, it is a flexible construct, entangled with power relations, social hierarchies, and human imagination. It is temporary, and it is constantly in the process of being constructed. Likewise, the re-mapping discloses the "vacillating" feature of the border itself-that is, the border is not always found at the demarcation line inscribed on a map since it tends to be fluid, "duplicated, multiplicated and projected below and beyond the line itself" (Cuttitta 61). By this logic, any border concept must be understood as an entity that shifts from fixed line to a mobile one, from a material division to an immaterial one, and finally from a linear demarcation to a zonal one. Borders, therefore, are no longer understood only as lines on a map but as spaces in their own right - borderlands and borderzones - and, more importantly, as processes of b/ordering.

Furthermore, as the novel suggests, a borderless world is not the solution. The absence of borders would be a false utopia because it would not propose a life that is qualitatively different from existing conditions. Additionally, the borderless concept does not articulate concrete alternatives because it forecloses possibilities for which no terms of reference exist. Instead, it fixes the future based on contemporary material practices and discursive concepts, thereby reproducing ideologies that already exist. Even though globalization might suggest a borderless world for some people, the geopolitical subdivision of the globe suggests that borders are now dispersed, found not only at the geopolitical line, ubiquitous and polymorphic entities. As the protagonist claims towards the 
end, "'"Que I'homme est malheureux qui au monde se fie! La matière demeure [même si] la forme se perd" (139).33 Therefore, instead of bypassing borders in favour of an immediate transnationalism or cosmopolitanism that risks ending up nowhere, one should favour "Incantations et prières pour faire marche arrière," ${ }^{34}$ as the last sentence of the novel suggests (158).

\section{Conclusion}

Le Baiser de Lampedusa allows the reader to reflect upon the nature of a world in which national and supra-national borders are no longer assumed as natural: it urges the reader to connect the novel's speculative events with anti-immigration legislation, European neoliberalism in the form of economic agreements with African countries, and the current militarization of the Mediterranean border. Its fictional literary cartography resonates with the circumstances of present times in which not only capital but also borders and their intrinsic military defense are premised on flexibility. Finally, its counterfactual scenario represents a challenge to the tenets of globalization. How far is the world willing to take the idea of free circulation?

In the novel, geography is not a simple backdrop within the fiction, but almost a protagonist. The Mediterranean Sea is not only the locus of interaction of dynamic forces, it also becomes an actor, the agent of the counterfactuality. Furthermore, it represents an entity capable of provoking actions and events while also having control over the characters' existence. Constantly in motion, the literary cartography proposed by Charfi represents the elasticity of borders. It stresses the constantly shifting and contested dynamics of social power and highlights that categories such as borders, continents and nations are constantly invented and reinvented in the process of becoming and/or disappearing.

The critical perspective of Le Baiser de Lampedusa lies in its very genre. The counterfactual literary cartography defies existing maps and urges the reader to escape from their constraints in order to explore and speculate on possible 
sequences of events. It encourages one to obtain the understanding of the world through a system of correspondence between natural phenomena and social mechanisms. Charfi carries out his alchemical search for a universal equilibrium through a configuration of multiple contingent possibilities, all present yet none inevitable. His "literary alchemy" defamiliarizes the object of analysis (the sea) and the established method (geography) in order to delve into possible alternative forms of knowing, thinking, and being. He creates a space of reckoning that allows us to reflect on potential contingencies and possibilities and consider unthought-of alternatives so that we may imagine a different future. Charfi's experiment is not a project of merely describing the present differently but one of stressing its impasses, elisions, and entanglements. It is an attempt to reveal the existence of alternatives and possibilities that lay within, to read connections and conjunctions across archives and geographies, and to devise other modes of interpretation beyond the assumptions based on geopolitics, economics, and religion.

Even though it takes the form of a flight from reality, the novel contains an implicit critique in its subversive technique, which intrudes upon the cartographic "real" by undermining its spatial points of reference and certainties. The deviation from the "real" is employed to frustrate any faith in existing configurations, and it has the ability to re-frame the existing sense of reality. Its dual re-mapping - of turning towards a possible future as well as towards the present in order to narrate the Mediterranean's position in contemporary geopolitics - reveals the ambivalence and complexities of the Mediterranean borderscape as an unfolding process. Charfi's fictional cartography speculates on the future in order to explore the problems of the present and draws on the power of the imagination to depict alternative visions of unexplored connections among various individuals and communities that inhabit the borderscape. 
In light of alchemy's struggle after the unattainable, and of the principle of unity of matter (Read 278), Charfi's "literary alchemy" transforms the EuroAfrican borderscape into a unified space, only to indicate that the transformation could not be a promising - or golden - solution. The novel's concluding remark criticizes such a questionable alternative, proposing a necessary shift in our way of thinking that, instead of visualizing "utopian" futuristic scenarios, should involve a reflection on the past. The geographical space that the Mediterranean Sea occupies is intrinsically connected to the history of the region, without which it would be impossible to comprehend the stratiform dimension of this basin. The spatial dimension is therefore inseparable from the temporal and historical one, while any cultural and political achievements depend on the interplay between history, geography, people, and cultures. In other words, the Mediterranean basin, and the world itself, is like an open book requiring the appropriate device to be interpreted. Nevertheless, since our interpretations are destined to be incomplete, we will never arrive at the bottom of things. In this sense, the investigation into and speculation about the "possible" remain open, as the conclusion of the novel demonstrates. And yet, if, at the end, we are forced to acknowledge that there is no clear outcome or simple way out of this intricate web, then it becomes all the more fundamental to recognize its limitations. The only possible trajectory to resolve contemporary critical conditions is to look into the present, consider the traces of the past and, from such analysis, obtain a wiser sense of the possible.

\section{Endnotes}

\footnotetext{
${ }^{1}$ Literary scholars define counterfactual as theoretical alteration or mutation of a sequence of events made in order to construct a different version of reality that counters the events of the "real," or factual, world. The term "counterfactual" means, literally, contrary to facts (Dannenberg 110).

${ }^{2}$ The verb to speculate suggests inconclusive thoughts, but the term carries with it a sense of expectation or concern and opens opportunities beyond the so-called "real" or "fact." To speculate upon something does not take exclusive interest in predicting the future. Rather, since, etymologically, it derives from spectacle and spectator, the term connotes observation, contemplation, and consideration.
} 
${ }^{3}$ Fiction does not reproduce the real but interacts with the real according to the logic of interfaces/referentiality. Accordingly, one could say that all literary productions are ontologically counterfactual if one understands counterfactual in its sense as fictive production. Yet any fictive literary production represents imagined scenarios, while counterfactual fictions describe alternative scenarios to outer reality. The idea that frames the present article is that fiction does not reproduce the real. Rather, as Westphal has noted, "[fiction] actualizes new virtualities that had remained unformulated, and that then go on to interact with the real according to the hypertextual logic of interfaces" (103).

${ }^{4}$ The term borderscape is inspired by Arjun Appadurai's theory of "scapes" (1990) and refers to a grid of signs and versions of the very border that stretches out from its geopolitical locations and insinuates itself into different fields of social life (Brambilla 2010).

${ }^{5}$ In their article "Fabrica Mundi: producing the world by drawing borders" (2013), which presents excerpts from the book titled Border as Method, or, the Multiplication of Labor (2013), Sandro Mezzadra and Brett Neilson analyze the power of cartography in shaping the world according to its measures. Accordingly, "cartography congealed the ontological moment of the fabrication of the world, an abstracted fabrica mundi to be projected onto maps. The naturalization of geographical and cognitive borders was the necessary outcome of this epistemological move" (11).

${ }^{6}$ The author seems to suggest what the Italian scholar Franco Farinelli has claimed in I segni del mondo: the map, with its intrinsic power of representation and capacity to act within the social dynamics, "is above all a project on the world [...] and the project of each map is the one to transform, beforehand, the earth's face in its own image"("[o]gni carta è innanzi tutto un progetto sul mondo [...] e il progetto di ogni carta è quello di trasformare -giocando d'anticipo- la faccia della terra a propria immagine e somiglianza"; my trans.; 77).

${ }^{7}$ According to Westphal, the interface consists of "a line for instant communication between real and fictional" that lies in "words, in a certain way of positioning them along the axis of truth, verisimilitude, and falsity, away from any old mimetic fancy or all axiology" $(99,77)$.

8 "I lost myself within the reconfiguration of the world, I imagined myself as a juggler of planets" (my trans.; all subsequent translations are mine unless otherwise noted).

9 "I had a sole and unique obsession: to find the first volume in order to read the second one."

10 "an event [produced] by the bowels of the earth, much deeper that its geological layers, in its liquid and burning abyss."

11 " has finally found a way to converge faster the two sides of the wound [...] that is the Mediterranean. It will be able to suture the coastal cities.".

12 "an immense bruise that has been made on the body of the earth[,] [...] a piece of earth occupied by thirty million human beings, who feel obliged to not get involved in the existence of their neighbours, [who] are, like roots, attached to the piece of earth underneath their feet.".

${ }^{13}$ The border figure of the wound has also been employed by the Chicano artist and scholar Gloria Anzaldúa in her Borderland/La Frontera to describe the U.S.-Mexico border. Accordingly, the border wound is a traumatic historical space that keeps influencing contemporary experiences of people and populations living in the borderland. For her, the U.S.-Mexico border is a "mile-long open wound/dividing a 'pueblo', a culture/ running down the length of the body/ staking fence rods in my flesh/splits me, splits me / me raja, me raja" (2). Also, in his posthumously published text, Memory and the Mediterranean, Fernand Braudel motions to a beginning of history before human beings, and he refers to the Mediterranean as an ancient scar on the terrestrial globe: "if the Mediterranean seems so alive, so eternally young in our eyes [...] what point is there in recalling this sea's great age? What can it possibly matter, that the Mediterranean, an insignificant breach in the earth's crust, [...] is an ancient feature of the geology of the globe?" (3).

14 "[T]housands of Africans threw themselves into European barbed wires, their bodies were mutilated by nails, blows and bullets ... Some of them were caught and thrown back like mangy dogs ... Those who survived came always back to those barbed wires. Their only code word was: pass or die ... They had to cross the sea by paying human smugglers using an entire life's savings or by advanced payment based on slavery contracts. Once they became clandestine, they drowned their sufferings inside the holds of the feluccas. During the crossing, the smell of fuel oil suffocated their dread of being caught by coastguards. And this short journey turned often into a drama: at the smallest mishap, they were thrown overboard by their heartless hosts and they finished their journey inside the jaws of sharks." 
15 "who do not know each other, or who did not really see each other."

16 "[it] could upset everything ... Suddenly, a powerful halo wipes the past away while the future starts sparkling with raging mad mirages. Starting from this rift in the human crust, the desire for the Other inflates and merges, all the while redefining different limits and different provisional paths. The Other becomes mine, his/her thought is adopted. From now on, his/her adored gaze becomes reference, like a lighthouse. His/her perspective becomes ours. We proceed along his/her tracks as if we had never walked on any other path.".

17 The terms third space and hybrid are used in the sense given by Homi Bhabha, for whom hybridity operates as a "reversion of the effects of the colonialist disavowal, so that the other denied knowledge enters upon the dominant discourse and estranges the basis of its authority", while the third space is the cultural location of hybrid communities (114).

18 "[t]hat's not love anymore [...] It's madness!".

19 "the puzzle was recomposing itself."

20 "the universe is the nation of the man. Borders are just the leftover of a colonial conception that is doomed to disappear. Men are supposed to move freely like goods".

21 "[S] he was a worker in a textile factory for export to France, a factory whose owners were benefiting from all tax and social advantages, a factory where the workers were doing three eight-hours shifts under conditions of modern slavery, where any mistake was punished by a pay reduction ... She started calculating how many millions of dinars her boss gained from her twenty years of miserable existence, working in front of the sewing machine.".

22 "the new colonized who lock themselves within the walls of their luxurious ghettos." .

23 "this immense moving human anthill." .

24 "a hymen erected to the virginity of Europe."

25 "the penetration of unauthorized African populations."

${ }^{26}$ According to Manfred Pfister, this myth is a foundational model for territorial identity politics, which are still effective in our present. What is vital for territorial or cultural unity and identity "is less the projection of some core essence than the demarcation of boundaries, and it is through defining and policing margins and through constructing differences between inside and outside, self and Other, more than through unification within that cultural entities like Europe are created" (24-5; emphasis in original).

27 " [...]people without profits and promises."

${ }^{28}$ Alchemy was a medieval science that sought to change ordinary metals into gold. The alchemist saw himself as one who, although operating within the traditional worldview, was able to alter and manipulate the normal course of nature through knowledge and experience. The art of transforming and manipulating the course of things functions simultaneously on three levels: the physical, the mental, and the spiritual. Yet, no transformation would be lasting or complete unless it succeeded in all three levels (see Linden 2003).

29 "our Mediterranean becomes a dead sea ... and for a piece of Promised Land, people kill each other." .

30 "the wide universal/global family of people is utopia."

31 "we do not need any alchemy volume to comprehend life. The earth, the men and the sky will move in one way or another and it will not be my hand to stop them."

32 "neither a wizard nor a seer.".

33 "miserable is the man who trusts the world! ... The matter [the border] will remain [even though] the shape disappears." .

34 "Incantations and prayers in order to turn back." 
(0)

\section{Works Cited}

Anzaldúa, Gloria. Borderlands/La Frontera: The New Mestiza. Spinsters/Aunt Lute, 1994. Appadurai, Arjun. Modernity at Large: Cultural Dimensions of Globalization. U of Minnesota P, 1996.

Ben Slimane, Fatima. "Between empire and nation-state: the problem of borders in the Maghreb." Mediterranean Frontiers: Borders, Conflict and Memory in a Transnational World, edited by Dimitar Bechev and Kalypso Nicolaidis, Tauris Academic Studies, 2010, pp. 35-55.

Bhabha, Homi K. The Location of Culture. Routledge, 1994.

Brambilla, Chiara. "Pluriversal, Citizenship and Borderscapes."Transient Spaces: The Tourist Syndrome, edited by Antje Weitzel and Marina Sorbello, Argobooks, 2010, pp. 61-65.

Braudel, Fernand. Memory and the Mediterranean. Translated by Siân Reynolds, Random House, 2001.

Chambers, Ian. Mediterranean Crossings: The Politics of an Interrupted Modernity. Duke UP, 2008.

Charfi, Mounir. Le Baiser de Lampedusa. Arabesques, 2011.

Cuttitta, P. "Points and Lines: A Topography of Borders in the Global Space." Ephemera:

Theory and Politics in Organizations, vol. 6, no. 1, 2006, pp. 27-39.

Dannenberg, Hilary. Coincidence and Counterfactuality: Plotting Time and Space in Narrative Fiction. U of Nebraska P, 2008.

De Certeau, Michel. The Practice of Everyday Life. Translated by Steven Rendall, U of California P, 1984.

Donnan, H. and Haller D. "Liminal No More: The Relevance Borderland Studies." Ethnologia Europaea, vol. 30, no. 2, 2010, pp. 7-22.

Farinelli, Franco. I segni del mondo: Immagine cartografica e discorso geografico in età moderna. La Nuova Italia, 1992. 
Harvey, David. The Condition of Postmodernity: An Enquiry into the Origins of Cultural Change. Blackwell, 1989.

Linden, Stanton J. The Alchemy Reader: From Hermes Trismegistus to Isaac Newton. Cambridge UP, 2003.

Lowe, Lisa. The Intimacies of Four Continents. Duke UP, 2015.

Mezzadra, S. and Neilson B. "Fabrica mundi: producing the world by drawing borders." Scapegoat: Architecture, Landscape, Political Economy, Currency, vol. 4, pp. 3-19.

---. Border as Method, or, the Multiplication of Labor. Duke U P, 2013.

Newman, David. "The lines that continue to separate us: borders in our 'borderless' world." Progress in Human Geography, vol. 30, no. 2, 2006, pp. 143-161.

Pfister, Manfred. "Europa/Europe: Myths and Muddles." Myths of Europe, edited by Richard Littlejohns and Sara Soncini, Rodopi , 2007, pp. 21-33.

Prieto, Eric. "Geocriticism, Geopoetics, Geophilosophy, and Beyond." Geocritical Explorations, edited by Robert Tally, Palgrave Macmillan, 2011, pp. 13-28.

Read, J. "Alchemy and Alchemists." Folklore, vol. 44, no. 3, 1933, pp. 251-278. Ribas-Mateos, Natalia. "Revising Migratory Contexts: The Mediterranean Caravanserai." The Mediterranean Passage. Migration and New Cultural Encounters in Southern Europe, edited by Russel King, Liverpool UP, 2001, pp. 22-40.

Rivera-Servera, Ramón H. "Border Moves." Performance in the Borderland, edited by Ramón Rivera-

Severa and Young Harvey, Palgrave Macmillan, 2010, pp. 1-16.

Tally, Robert T. Spatiality. Routledge, 2013.

Westphal, Bertrand. Geocriticism: Real and Fictional Spaces. Translated by Robert Tally, Palgrave Macmillan, 2011.

Widmann, Andreas Martin. "Towards a Typology of Counterfactual Historical Novels." Counterfactual Thinking and Counterfactual Writing, edited by Dorothee Birke, Michael Butter and Tilmann Köppe, Walter de Gruyter, 2001, pp. 170-89.

Silvia Ruzzi is a PhD student in the Faulty of Cultural Theory and History at Humboldt University Berlin. 
RETURN TO CONTENTS (LINK) 